February 15, Sir William Prescott, chairman of the Metropolitan Water Board, stated that the "site for the proposed reservoir at Walton has been selected after the most exhaustive examination of other available lands". It is not stated whether the expert opinion available to the Ministry of Agriculture or to the Geological Survey has been sought, but it is much to be hoped that such scientific advice may be consulted before the matter comes under discussion in committee of the House of Commons.

\section{A New American Balloon Ascent into the Stratosphere}

Following on the American ascent into the stratosphere last year recorded in NATURE of July 28, p. 132 and November 3, p. 707, 1934, careful inquiry has now shown that the mishap was caused by internal adhesions of the lower part of the balloon fabric. Plans for a new ascent are well advanced. The personnel of the advisory committee has been chosen by the National Geographic Society working in co-operation with the United States Army Air Corps, and once again Capts. A. W. Stevens and O. A. Anderson will ascend. It is gathered from the announcement by the president of the Society in the National Geographic Magazine of February 1935 that the arrangements will differ but little from those of last year's flight. The balloon will have the same capacity and the ascent will be made from the same place. No details are as yet available of the instruments that will be carried, but as the lifting power will be about six tons and as "special emphasis is to be placed on data that can be obtained from manned balloons capable of lifting standard laboratory instruments", there is no doubt that every possible self-registering device that might supply information about the upper atmosphere and cosmic rays will be included. An advisory committee under the chairmanship of Dr. Lyman J. Briggs, director of the U.S. Bureau of Standards, is to be congratulated on the thoroughness of its investigations of the previous failure. The findings will be of greatest value to those who undertake future hazards.

\section{A New Diphtheria Prophylactic}

OwING to the prevalence of diphtheria during the last year, a considerable demand has followed for immunising agents for preventive. inoculation, which is now extensively practised with good results. Various agents have been employed for this purpose, such as toxin-antitoxin mixtures and preparations of modified diphtheria toxin known as 'toxoid'. An alum-precipitated toxoid (A.P.T.) of high immunising efficiency is now available, and is issued by Messrs. Burroughs Wellcome and Co., in germ-proof containers of 1 c.c. and 5 c.c. This substance was first prepared in the Wellcome Physiological Research Laboratories in 1926. The results of animal tests showed that it possessed considerable immunising power against diphtheritic infection, and since that date its high immunising efficiency in human beings has been established. Caution has been exercised in applying the inoculation of A.P.T. in human beings on account of the production of a tissue response at the site of injection. This, though medically trivial, may disturb parents of inoculated children. The efficiency of A.P.T. probably depends upon the deposition of the relatively insoluble aluminiumtoxoid compound at the site of injection, and from this the immunising toxoid is gradually liberated. The complex toxoid compound, however, excites a tissue response in the form of a small painless nodule, and this tissue response is probably an essential factor in the potent immunisation that ensues, Unpublished experiments made in the Wellcome Research Laboratories have shown that in animals two spaced injections of one tenth, or less, of the ordinary human dose results in a more rapid, or a higher, immunity than one single larger dose. It is possible that a similar method may prove useful in human immenisation, the chance of troublesome local reaction being lessened by this course.

\section{Juan Fernandez and Easter Island}

By a recent decree of the Chilean Minister of Lands and Colonisation, it is reported by a correspondent of The Times in the issue of February 14, Juan Fernandez and Easter Island have been declared national parks. This gives effect, so far as Juan Fernandez is concerned, to a proposal which was first put forward so long ago as 1921. The two volcanic islands grouped together under the name Juan Fernandez and situated four and five hundred miles respectively west of Valparaiso are of popular interest because it was on one of them that Alexander Selkirk was marooned from 1704 until 1709; and his adventure is supposed to have inspired Defoe in writing "Robinson Crusoe". Easter Island, on the other hand, which lies about 2,300 miles from the mainland, is one of the most interesting islands of the Pacific. Its archæological remains present a problem for ethnologists which hitherto has defied satisfactory solution. These remains consist of more than five hundred human figures, portrait statues, carved in stone, some of gigantic size and one at least approaching forty foet in height, over two hundred stone platforms and stone houses, unique in the Pacific, relics of a race of which the present inhabitants have no knowledge. Even more interest. ing in certain respects are the tablets inscribed in a script which no one has yet succeeded in deciphering. Since 1888 the island, which has an area of about 48 square miles, has been in the possession of Chile, and has served as a penal settlement. The native inhabitants, who are Polynesians with a Melanesian strain, barely exceed 200 in number, though in 1860 they numbered 3,000 ; but in the 'seventies a considerable proportion migrated or was removed to Tahiti and the Gambier archipelago. The decree of the Chilean Government, in so far as it will ensure the protection from vandalism of these unique relics of an otherwise unknown culture and an apparently vanished race, is a public-spirited act worthy of the highest commendation.

\section{A Tidal Power Project in the Bay of Fundy}

THE Bay of Fundy is well known throughout the world for the height of its tides. It is not surprising, therefore, that Americans are interested in the 
project for getting tidal power at Passamaquoddy Bay, which lies between New Brunswick, Canada, and Maine, U.S.A. A full description of the project is given by H. E. M. Kensit in World Power of February. The projected power house is situated entirely in the State of Maine, but as the project is an international one, the power produced would be equally divided between the two countries. If we compare the estimated cost of the new project with that of the corresponding tidal power schemes in England (the Severn) and in the Argentine (San José) it comes out decidedly cheaper. In the English scheme, the cost of a horse-power is $£ 31 \cdot 4$, in the Argentine it is $£ 25 \cdot 3$ and at Passamaquoddy it is $£ 18 \cdot 9$, and each is roughly of the same size. The normal spring tides at the head of the Bay of Fundy range between $47 \mathrm{ft}$. and $52 \mathrm{ft}$. The maximum recorded tide occurred in 1869 and was nearly $57 \mathrm{ft}$. At the site of the new power station, the tides will lie between $17 \mathrm{ft}$. and $19.5 \mathrm{ft}$. In 1930, President Hoover induced Congress to defray half the cost of a joint investigation with Canada into the effect of such a station on fisheries. In this connexion, it is of interest to know that the committee on the Severn project decided that a large number of sluices open for many hours every day would obviate any detriment to fishing interests. It is probable therefore that the joint commission on fisheries may present a favourable report. The United States engineers indicate that there is no insuperable difficulty with regard to shipping interests, and many are hoping that this great enterprise will be carried out by private interests and capital.

\section{Habits and Evolution}

AT the annual conference of the School Nature Study Union, held in January, Prof. E. W. MacBride was the speaker, and his address upon "The Allimportance of the Study of Habits for the Knowledge of Evolution" was, in effect, a statement of his evolutionary faith (School Nature Study, 1935, p. 2). He led to his own viewpoint by a vigorous onslaught upon the faiths of others. Evolution we all accept, but the way thereof is dark. Darwin, we learn, with his natural selection of variations, was a false prophet, for natural selection does not work even if smali deviations were heritable, which they are not. The mutationists are equally in error, for a mutation is a suddenly produced disturbance of develspment which persists only so long as the conditions producing it continue. According to Prof. MacBride, the truth lies with the neo-Lamarckisns in their belief that use and disuse, in short habit, have been the mainspring of the progress of evslution. "Habit long persisted in does affect pos'ierity and is the driving force in evolution; the personality, if we may use such a word, of a living being, is made up of a complex of inherited hebits, and habits deeply ingrained are extraordinarily persistent." Prof. MacBride supports his thesis and trounces his opponents by quoting experimental results well selected for his purpose. Thirty years ago no biologist would have listened to the Lamarckian view ; nowadays we are not so sure.

\section{Scheme for Eradication of Cattle Tuberculosis}

The Ministry of Agriculture and Fisheries has issued a document describing 'arrangements' made by the Ministry under Section 9 of the Milk Act, 1934, for promoting the establishment of cattle herds officially certified to be free from tuberculosis. Any owner who has taken steps to eradicate the disease from his herd, and is a 'registered producer' under the Milk Marketing Scheme, is entitled to apply to the Ministry for an official test of his herd, providing no reactors were found in the herd at the last two tests made under certain conditions on the owner's behalf. If the owner satisfies the Ministry as to the management and conditions of herd and farm, and agrees to observe the regulations, an official tuberculin test of the herd will be made by the Ministry free of charge, and provided no reactors are found, the herd will be placed upon a 'register of attested herds'. The scheme, which is a voluntary one, came into operation on February 1, and owners who desire to avail themselves of it should communicate with the Secretary, Ministry of Agriculture and Fisheries, Whitehall Place, London, S.W.1. One advantage of attestation is that the owner will be entitled to a bonus of $\mathrm{l} d$. per gallon for all milk sold under the marketing scheme of the Milk Marketing Board.

\section{Iodine and the Thyroid Gland}

Is the twenty-ninth Bedson Lecture delivered on February 8 in Newcastle, Prof. C. R. Harington dealt with the relation of the thyroid gland to iodine. He traced in detail the parallel histories of the anatomy, physiology and pathology of the gland, culminating in the work of Kocher, the treatment with sheep gland extracts by Murray, and the iodine treatment by Coindet of goitre and cretinism. Although the 3 : 5-diiodotyrosine also present in the 'colloid' must take part in the activity, as this is proportional not to total thyroxine but to total iodine, the two dipeptides made from them have not proved to show the full activity, so that possibly they are linked to, or by, other amino-acids, it being fairly established that no other compound of iodine is present. The general picture, then, is as follows. Iodine is readily taken up by the gland with formation of $3: 5$-diiodotyrosine, which is elaborated into the globuline; this is the storage form, the so-called 'colloid', of the epithelial layer. When total iodine in the gland falls below 0.1 per cent, the colloid is soon exhausted and the epithelium extends to form goitre. Later, generally in pre-natal conditions, atrophy occurs leading to cretinism. Restoration of iodine at the former stage leads to distension by colloid, and the epithelium reabsorbs. In the normal state the tyrosine derivative is partly converted into thyroxine, and these two substances form the hormone which regulates bodily metabolism in general. In support of this view, it has been shown by Prof. Harington that the tyrosine and thyroxine are of the same stereochemical configuration by the preparation from each of thyronine (desiodothyroxin). 